ББК 63.3

УДК 94(571)«1940/46»:393(571.150-25)

\title{
Из истории образования на Алтае: польские школы в Барнауле (1940-1946 гг.)
}

\author{
И.Н. Никулина, О.А. Литвинова
}

Алтайский государственный технический университет им. И. И. Ползунова (Барнаул, Россия)

\section{From History of the Education in Altai: Polish Schools in Barnaul (1940-1946)}

\author{
I.N. Nikulina, O.A. Litvinova \\ Polzunov Altai State Technical University (Barnaul, Russia)
}

В статье освещен процесс функционирования школ для польских детей, оказавшихся в условиях Второй мировой войны на территории Сибири, в том числе в Барнауле и на близлежащей к городу территории. Авторы уточнили фактологические сведения о школах, содержащиеся в публикациях других исследователей. Для этого были введены в научный оборот не привлекаемые ранее архивные материалы и документы из Музея Независимости в Варшаве. Авторы изучили официальные сведения об этнической принадлежности учеников барнаульских школ и сделали вывод о возможном обучении в школах города детей поляков-спецпереселенцев. Отмечено несоответствие информации о числе польских школ, представленной в публикациях польских исследователей, сведениям, обнаруженным в настоящий момент в региональном архиве. В связи с этим сформулировано предположение, что информация о некоторых польских школах могла не попасть в официальные документы отдела народного образования Барнаула. Поднят вопрос о соотношении субъективных и объективных факторов в процессе развития польского национального образования на территории СССР, в том числе в Барнауле. Авторы обратили внимание на материальную помощь, которая была оказана региональным отделением Союза польских патриотов польской школе и польскому детскому дому.

Ключевые слова: польские школы, польский детский дом, образование, спецпереселенцы, Союз польских патриотов, Вторая мировая война.

DOI 10.14258/izvasu(2019)6-06

Проблема депортации польского населения в Сибирь в годы Второй мировой войны является одной из малоизученных в отечественной историо-
The article studies functioning of schools for Polish children in situations of the Second World War in Siberia, including Barnaul and the territory adjacent to the city. The authors clarified the factual information about schools contained in the publications of other researchers. To do this, the authors revealed and put into scientific circulation archival materials and documents from the Independence Museum in Warsaw. The authors studied official information about the ethnicity of the pupils of Barnaul schools and concluded that the children taught in the city's schools could be Poles special settler. The article noted inconsistency of information on the number of Polish schools, presented in the publications of Polish researchers, to the information found at the moment in the regional archive. In this regard, it is the authors suggested that information about some Polish schools not have been included in the official documents of the Public Education Department of Barnaul. The article raises the question of the ratio of subjective and objective factors in the development of Polish national education in the USSR, including in Barnaul. Revealing this question, the authors drew attention to the material assistance that was provided by the regional branch of the Union of Polish Patriots to Polish school and Polish children's home.

Key words: Polish schools, Polish children's home, education, special settler, Union of Polish Patriots, Second World War. графии. В рамках обозначенной проблемы существует ряд аспектов, которые можно исследовать как самостоятельные темы. Одной из тем такого рода 
является вопрос о функционировании в Сибири, в частности в Барнауле, школ для детей польских переселенцев.

В настоящее время можно назвать лишь одну публикацию, в которой освещен процесс формирования института польского национального образования на территории Алтайского края в военный период. Это статья Э. Трели-Мазур [1, с. 422-427]. Польский исследователь проанализировала специфику становления и развития польского образования на протяжении военных лет и первого послевоенного года в контексте советско-польских отношений. Несомненной заслугой Э. Трели-Мазур является представление информации о численности польских школ и учеников в них на 1 января 1946 г. Важно отметить, что исследователь раскрыла роль субъективного фактора в процессе создания польских школ, в частности, предоставила информацию о деятельности депортированной на Алтай Л. Милевич. Между тем наличие публикации Э. Трели-Мазур делает необходимым уточнить представленный ею фактологический материал и определяет задачу более полно проанализировать объективные факторы в развитии польского образования на Алтае в обозначенный хронологический период.

Потребность в изучении проблемы формирования и функционирования в Алтайском крае образовательных учреждений для детей поляков заставила нас всесторонне изучить публикации, в той или иной степени затрагивающие тему депортации и эвакуации польских семей в восточные регионы СССР. Среди авторов, обращавшихся к указанной тематике в последние десятилетия, следует назвать Ю.В. Иванова [2, с. 44-52], М.А. Авимскую [3, с. 181-182], И.А. Ложкину [4, с. 156-162], А. Подборскую [5]. Наиболее глубокий анализ проблемы пребывания польских детей на территории СССР в годы Второй мировой войны дан в статье Ю. В. Иванова. Названный историк, обращаясь к материалам архива внешней политики РФ, представил исторические факты, касающиеся системы снабжения польских учреждений, работы отдельных детских домов для польских детей, деятельности институтов советского государства по оказанию помощи польским детям, а также противоречий между советским и польским эмигрантским правительством по поводу польских детей, находящихся на территории СССР.

Анализ функционирования системы опеки над польскими детьми в отдельных регионах СССР представлен в публикациях И.А. Ложкиной и М.А. Авимской. Так, процесс создания и работы детских домов для эвакуированных польских детей на территории Удмуртии освещен в статье И.А. Ложкиной [4]. В публикации М.А. Авимской показана динамика становления системы соцзащиты над детьми в Тюменской области [3]. А. Подборская представила развернутые сведения об условиях проживания семей поляков-спецпереселенцев на территории Красноярского края [5].

Исследование тематики пребывания польских детей на Алтае было бы неполным без изучения вопроса о депортации поляков на Европейский Север СССР и в Сибирь. Краткие сведения о спецпереселенцах польской национальности в Сибирском регионе представил в своей монографии С.А. Папков [6]. Богатый информационный материал, как по количеству депортированных в Алтайский край поляков, так и по объему получаемой ими гуманитарной помощи, представлен в статье В.А. Скубневского [7, с. 103-112]. Системный анализ различных форм духовного протеста в среде спецпереселенцев в 1930-1950-е гг., в том числе и в среде депортированных поляков, содержит публикация Н.М. Игнатовой $[8$, c. 5-13].

Наконец, необходимость исследования проблемы функционирования польских школ заставила нас обратиться к истории развития польского национального образования в Сибири. В этом плане оказалась полезной статья Л.К. Островского [9, с. 23-29], посвященная развитию польского просвещения на территории Западной Сибири, несмотря на то, что верхняя граница хронологических рамок этого исследования ограничена началом 1920-х гг. Таким образом, анализ исторических публикаций позволяет сделать вывод, что вопрос о формировании и развитии на Алтае школ и социальных учреждений для польских детей требует дальнейшего изучения, поскольку необходимо расширение документальной базы исследования с привлечением архивных материалов, в частности материалов Государственного архива Алтайского края (ГААК).

Осмысление процесса развития польского национального образования в СССР в годы Второй мировой войны ставит задачу определить причины прибытия на территорию Сибири детей польской национальности. Первая причина появления в сибирском регионе польских детей связана с проводимой в первой половине 1940 г. «зачисткой» приграничных территорий СССР от «неблагонадежного элемента», т.е. с депортацией польского населения. Депортация поляков на восток страны была следствием внешнеполитического курса советского правительства: подписанием в 1939 г. пакта МолотоваРиббентропа и последовавшей за этим аннексией территории Восточной Польши. Историки, характеризуя происходивший в 1940 г. процесс депортации поляков, применяют понятие «этническая ссылка» [6]. Поляки-спецпереселенцы делились на две категории - осадники и беженцы. К осадникам относились преимущественно участники советско-поль- 
ской войны 1920-1921 гг., получившие на территории Восточной Польши в 1920-е гг. земельные наделы. По этой причине среди осадников преобладали этнические поляки. В условиях начавшейся Второй мировой войны советское правительство считало эту категорию населения потенциально опасной, что и стало причиной высылки людей. Историки обращают внимание на то, что понятие «осадник» трактовалась советским правительством весьма широко, поэтому под депортацию подпадали не только бывшие военнослужащие польского происхождения, но и другие представители сельского населения бывшей Восточной Польши (Западной Украины и Западной Белоруссии). В отличие от осадников к беженцам относились лица преимущественно еврейского происхождения, перебравшиеся на территорию Западной Украины и Западной Белоруссии из оккупированных Германией в сентябре 1939 г. территорий Польши. Депортация поляков-осадников началась в феврале 1940 г., а в июне-июле того же года началось переселение польских беженцев. Ввиду того, что под депортацию подпадали семьи поляков, в регионах, куда эти семьи были отправлены, оказывались дети.

Вторая причина появления на территории Сибири польских детей заключалась в эвакуации сиротских домов. Ю.В. Иванов отмечает, что основной контингент польских детей, оказавшихся на территории СССР, сформировался по причине эвакуации сиротских и детских домов из Западной Украины, Западной Белоруссии и Литвы. Уже оказавшись на территории Сибири, эти детские дома могли пополняться польскими детьми, депортированными вместе со своими родителями, но по ряду причин разлученными с ними.

Различие в причинах появления на территории Алтайского края польских детей объясняет факт существования в регионе как польских школ и детских садов, так и интернатов для польских детей при школах и польского детского дома [10].

Изучение вопроса о деятельности польских школ выдвигает ряд задач, требуемых решения. Первая задача - это уточнение данных о числе таких школ и численности учеников в них, вторая - изучение процесса становления школ для польских детей, третья - выявление особенностей образовательного процесса в польских школах.

Уточнение количественных данных о польских школах связано с выявлением численности депортированных поляков. Историки обращают внимание на сложность определения данных о контингенте поляков-спецпереселенцев. Согласно информации, представленной С.А. Папковым, на 1 января 1941 г. в Алтайский край было депортировано 10132 человека, из которых 6047 были осадниками, а 4085 - беженцами [6]. По мнению В.А. Скубневского, в пери- од 1941-1945 гг. по разным источникам численность депортированных в сибирский регион поляков варьировалась от 13 до 35 тыс. человек [7, с. 103-112]. Еще более сложной является задача определения количественных данных по польским детям, вывезенным из Западной Украины и Западной Белоруссии на восток советского государства. Это обстоятельство объясняется не только различными причинами переселения несовершеннолетних (депортация вместе с родителями или эвакуация сиротских домов), но и изменением возраста переселенцев, т.е. их переходом из категории детей в категорию взрослого населения. Ю.В. Иванов, ссылаясь на документы Архива внешней политики РФ, пишет о 66718 детей польской национальности в возрасте до 16 лет, указывая при этом, что только 1061 человек из них считались польскими гражданами [2, с. 44]. Иными словами, такие факторы, как расхождение количественной информации в источниках и исторических исследованиях, сложность определения этической принадлежности переселенцев, подвижность возраста, делают невозможным определить точное количество польских детей, оказавшихся в Алтайском крае в годы Великой Отечественной войны. Э. Треля-Мазур и В.А. Скубневский отмечают, что в Алтайском крае школы посещали около половины польских детей, в то время как в среднем по СССР - 25-28\% [1, с. 425; 7, с. 110].

Аналогично тому, как сложно найти точные сведения о количестве польских детей на Алтае, трудно подсчитать число польских образовательных учреждений. В «Летописи Барнаула» указывается, что в конце 1943 г. в краевом центре проживало 1,5 тыс. депортированных поляков, в Барнаульском сельском районе - 1,3 тыс. человек. Согласно этому же изданию, в 1943 г. в Барнауле было открыто семь польских детских садов и несколько польских классов в школах, а в школе № 2 обучалось примерно 147 польских учеников [11, с. 245]. Исходя из информации, представленной Э. Трелей-Мазур, в 1942 г. в Барнауле были открыты польские школы №1, 2, 3. На 1 января 1946 г. это были неполные средние семиклассные и семилетние школы с числом учащихся: в школе № $1-75$ (в первом классе -9 , во втором - 12, третьем - 17, четвертом - 18, пятом - 19 человек), в школе № $2-147$ (в первом - 16, втором - 20, третьем - 26, четвертом - 18, пятом - 20, в шестом - 22, седьмом - 25 учеников), в школе № $3-46$ (в первом - 10, втором - 16, в третьем - 8 , пятом - 12 человек). Иными словами, согласно данным польского исследователя, в школе № 2 обучалось самое большое количество польских учеников [1, с. 426-427]. Э. Треля-Мазур подчеркивает, что большинство польских школ создавались в Алтайском крае в 1942-1943 гг. [1, с. 425]. Однако при обращении 
к архивным документам, в частности к материалам фонда Алтайского краевого отдела народного образования, нами не было обнаружено информации о таких учебных заведениях. В отчете об итогах приема в школы Барнаула в 1942/43 гг. [12, л. 1-3] указывается этническая принадлежность учащихся. Из этого документа становится известно, что в барнаульской школе № 2 на начало 1942/43 учебного года из 665 учеников русских было 651 человек, остальные учащиеся - евреи, татары, эстонцы. Национальный состав учащихся барнаульских школ № 1 и № 3 в этом отчете не зафиксирован. Однако, принимая во внимание тот факт, что в сведениях о других школах города содержится информация об этнической принадлежности обучавшихся, можно сделать вывод, что в барнаульских школах №1 и № 3 обучались только русские дети, поскольку иная этническая ситуация нашла бы отражение в отчете. Заметим, что этот же отчет об итогах приема в барнаульские школы информирует, что в начальной школе № 40 обучалось три поляка и четверо евреев, а в неполной средней школе № 26 - двое поляков, пять украинцев и 17 евреев. При этом указывалось, что для 17 евреев родным языком был еврейский. Нами неслучайно обращено внимание на этническую принадлежность школьников. Понимая несоответствие числа польских учеников (пять детей) числу проживавших в Барнауле поляков, можно предположить, что эти пятеро учеников из школ № 26 и № 40 либо были из семей старожилов Барнаула, продолжавших себя идентифицировать с представителями польского этноса, несмотря на имевший место в 1920-е гг. процесс ассимиляции национальных меньшинств. Либо дети-поляки вместе со школьниками-евреями и украинцами были из числа спецпереселенцев-беженцев. Если наше второе предположение верно, то возникает несоответствие с информацией Э. Трели-Мазур о польских школах.

Считая необходимым уточнить информацию о польских школах Барнаула, мы обратились к показателям успеваемости школьников города за 1942/43 учебный год $[13$, л. 108, 196]. Этот архивный документ содержит списки учителей (классных руководителей) барнаульских школ военного периода, из чего следует, что в двух школах Барнаула школы № 1 и № 27 - есть фамилии, позволяющие предположить принадлежность преподавателей этих учебных заведений к польскому этносу. Речь идет о фамилиях Макатровская, Кисилевич (школа №1) и Кохановская, Адриановская, Паникаровская (школа № 27). Однако анализ исторического контекста склоняет нас к мысли, что упомянутые учителя были обрусевшими поляками. Кроме того, среди учителей школы № 1 не упоминается Лидия Милевич, которую Э. Треля-Мазур указывает как преподавателя именно польской школы № 1 в Барнауле. Таким образом, напрашивается вывод о том, что польские школы № 1, 2 и 3, работавшие в Барнауле во время войны, являлись самостоятельными учебными заведениями и не попадали в составленный отделом образования общий список барнаульских школ.

С целью расширения документальной базы исследования процесса становления польских школ в Барнауле работа с архивными фондами расширилась. Таким образом, нами был обнаружен протокол заседания исполкома Барнаульского городского Совета депутатов трудящихся от 18 сентября 1944 г., т.е. документ начала 1944/45 учебного года. В повестку дня указанного заседания был вынесен вопрос о предоставлении помещения для школы № 20. Исходя из принятого на заседании горисполкома решения можно сделать вывод о том, что упомянутое учебное заведение было школой, в которой обучались польские дети. Процитируем материалы заседания.

«В связи с необходимостью открытия на поселке ТЭЦ школы для польских детей и учитывая, что трест ОСМС «Стройгаз» представляет для этой цели барак на поселке ТЭЦ, исполком решил:

1. Разместить школу № 20 (школа для польских детей) в бараке Стройгаза на поселке ТЭЦ.

2. Обязать председателя Железнодорожного райисполкома т. Быкова и председателя Октябрьского райисполкома т. Анисимова в недельный срок предоставить Стройгазу по 4 комнаты для размещения ... живущих в бараке, предназначенном для школы польских детей.

3. Ремонт и оборудование помещения возложить на Краевой союз польских патриотов» [14, л. 135].

Полученная информация о польской школе, фигурирующей в документах под № 20, заставила нас тщательнее изучить архивные материалы, касающиеся этого заведения. В результате чего стало известно, что за год до принятия решения о предоставлении здания на поселке ТЭЦ школа № 20 располагалась на пос. Ильича (район кожевенного завода на окраине Барнаула), в ней обучалось 467 детей. Согласно сведениям о школах Барнаула, среди обучавшихся было пять украинцев и пять евреев. Исходя из отмеченной ранее специфики депортации населения Западной Украины и Западной Белоруссии (переселению подлежали не только этнические поляки, но и евреи с украинцами), можно выдвигать гипотезу, что в 1942/43 учебном году в этом заведении учились дети польских спецпереселенцев. Однако данная гипотеза может быть опровергнута приводимыми ранее сведениями из исследования Э. ТрелиМазур о численности польских школ и польских учеников. Кроме того, следует обратить внимание, что в Барнауле работали школы, где в 1942/43 учебном году обучалось большее число украинцев и евреев, чем в школе № 20. Например, в неполной сред- 
ней школе № 11, располагавшейся на ул. Полевой, что территориально было недалеко от изначального месторасположения школы № 20, учились 19 украинцев и 15 евреев при общем числе учеников в 689 человек. Начальную школу № 34 посещали 42 украинца и 56 евреев из 500 человек. В средней школе № 18 из 985 учащихся было 17 украинцев и пять евреев [12, л. 1-39 об.]. Выше мы представляли информацию об этнической принадлежности учеников школы № 26. Обратим внимание, что школы № 11, 18 и 20 находились в Октябрьском районе Барнаула, т.е. были территориально близки друг к другу. Таким образом, архивные материалы, введенные в настоящий момент нами в научный оборот, не позволяют дать точный ответ на вопросы: в каких школах Барнаула все же были польские классы, когда барнаульская средняя школа №20 стала школой для польских детей. Не исключено, что школа № 20 стала польской школой одновременно с принятием исполкомом решения о ее размещении в другом здании.

Важно отметить еще один факт: городские власти выделяли школе лишь здание. Что касается его ремонта и подготовки к учебному процессу, то эти функции возлагались на региональное отделение Союза польских патриотов (СПП). Эта общественнополитическая организация, созданная в марте 1943 г. и просуществовавшая до августа 1946 г., т.е. до репатриации основной части поляков, представляла интересы коммунистически настроенных польских эмигрантов. СПП имел региональные отделения, комиссии по социальному обеспечению и культурно-просветительные комиссии. Председатель Союза польских патриотов в СССР В. Василевская на пленуме Всеславянского комитета в ноябре 1943 г. как одну из задач Союза польских патриотов определила необходимость заботы о детях. «Мы получили от советского правительства право открывать польские школы в каждой местности, где находится хотя бы 25 польских детей. Создана государственная комиссия для работы среди польских детей. В эту комиссию входят и представители Союза польских патриотов. Надо нам было создать и издательство. До войны Германии против Советского Союза в Западной Украине и в Белоруссии работали издательства, выпускающие польскую литературу. С начала войны работа их прекратилась. Теперь у нас существует издательство, которое выпускает польские книги. И в первую очередь наша забота об обеспечении детей польских школ учебниками на родном языке», - сказала В. Василевская в ноябре 1943 г. [15, с. 27] Таким образом, оказание гуманитарной помощи полякам, оказавшимся на территории СССР, и реализация просветительской работы стали важнейшими направлениями в деятельности СПП. Ввиду этого СПП инициировал создание школ для польских детей, принимал меры по ор- ганизации обучения этих детей на родном языке. Соответственно, при создании польских школ СПП максимально брал на себя все материальные и организационные вопросы, что учитывалось советскими органами власти.

Факт существования в Барнауле в 1944/45 учебном году польской школы подтверждает еще один архивный документ 1944 г. - «Разнарядка по вывозу дров детскими и лечебными учреждениями с привлечением транспорта хозорганизаций по городу Барнаулу» [14, л. 225-226об.]. В этом документе уже без номера упоминается Польская школа (о школе под № 20 в документе при этом сведений нет). За Польской школой для вывоза дров закреплялся маслозавод № 3. Этому предприятию следовало вывезти для прикрепленного учебного заведения $10 \mathrm{~m}^{3}$ дров. У большинства других школ Барнаула количество дров, подлежащее вывозу, было больше (от 30 м $^{3}$

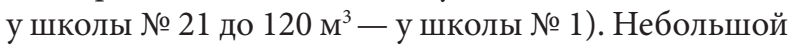
по сравнению с другими школами объем выделенных дров может свидетельствовать как о меньшем количестве учеников в Польской школе по сравнению с другими барнаульскими школами, так и о помощи СПП.

Возможное участие регионального отделения СПП в оказании материальной помощи Польской школе подтверждает отчет о движении материальных ценностей польского детского дома в с. Зудилове Алтайского края (по отчетным документам это учреждение названо детским домом №1 в с. Зудилово). Само село, расположенное в 30 км от Барнаула, в 1940-е гг. входило в состав Барнаульского сельского района. Э. Треля-Мазур в перечне польских школ и классов в Алтайском крае указывает, что в этом селе была польская начальная школа либо польский класс в начальной школе [1, с. 426]. Однако обращение к материалам периодики за 1944 г. позволяет сделать вывод о том, что в Зудилове функционировал польский детский дом. В частности, небольшая заметка, напечатанная 28 мая 1944 г. в центральной газете «Красная звезда», сообщает, что двумя днями ранее в Алтайском крае остановился проездом в США польский экономист, политический и общественный деятель, профессор Чикагского университета О. Ланге. При передвижении О. Ланге по СССР его сопровождали председатель комитета по делам польских детей Окшешевский и начальник отдела детских домов этого комитета Коняхина (инициалы ответственных работников в газетной статье не указаны. - И.Н., О.Л.). Корреспондент отметил, что после двухдневного пребывания на Алтае О. Ланге сделал представителю ТАСС заявление о визитах в польские детские сады Барнаула и о посещении занятий в четвертом классе барнаульской польской школы. Как сказал сам О. Ланге, «эти посещения оставили у меня прекрасное впечатление. Благодаря 
мероприятиям Советского правительства, усилиям Союза польских патриотов в СССР и заботам местных советских органов польские детские учреждения в Алтайском крае быстро развились и находятся в хорошем состоянии. Дети выглядят здоровыми, веселыми. Воспитательная работа с ними направлена на то, чтобы сделать из них достойных граждан свободной демократической Польши. Дети воспитываются настоящими польскими патриотами. Алтайский краевой отдел народного образования сделал все необходимое, чтобы, начиная с нового учебного года, все польские дети в Алтайском крае были охвачены учебой в школе». Также корреспондент газеты сообщил, что О. Ланге намеревался посетить польский детский дом, расположенный в с. Зудилове [16].

Авторами представляемой статьи обнаружен годовой отчет указанного детского дома [17, л. 53-61об.]. К отчету приложена объяснительная записка, из которой следует, что детский дом, помимо материальных ценностей, из бюджетных средств получил безвозмездно материальные ценности с польской базы в размере 52939 руб. Данная сумма является внушительной, если учесть, что всего материальных ценностей, согласно отчету, было получено этим детским домом в 1943 г. на сумму 56031 руб. [17, л. 61-61об.] Судя по документам, количество детей в польском детском доме в 1943 г. составляло 75 воспитанников, а на 1 января 1944 г. - 90 воспитанников [17, л. 56]. Если подсчитать материальные ценности, полученные с польского склада в денежном эквиваленте на одного воспитанника, то получится сумма в размере почти 706 руб. Для сравнения укажем, что на территории Алтайского края работали эвакуированные из европейской части СССР детские дома, вообще не получавшие безвозмездной помощи (большая часть детских домов была именно такой), а сумма материальных ценностей в денежном эквиваленте на одного воспитанника могла в отдельных детских домах составлять около 500 руб. Если же говорить об эвакуированных детских домах, получивших в том же 1943 г. безвозмездную помощь, то это был Днепропетровский детский дом № 4 (6697 руб. безвозмездного получения из 74057 руб.) [18, л. 221-234] и Грозненский детский дом № 4 (19317 руб. безвозмездного получения из 42775 руб.) [19, л. 75-79об.] Таким образом, из эвакуированных детских домов Алтайского края самая внушительная внебюджетная помощь была оказана польскому детскому дому. Учитывая специфику деятельности СПП, можно утверждать, что материальное обеспечение польского детского дома, расположенного в с. Зудилове Барнаульского сельского района, было организовано благодаря деятельности этой общественной организации.
Исследование деятельности польских школ немыслимо без изучения организации образовательного процесса в них. Инициатором обучения польских детей в Барнауле была Лидия Милевич, ставшая в дальнейшем учителем Польской школы в Барнауле (согласно сведениям Э. Трели-Мазур, польской школы № 1). По мнению Э. Трели-Мазур, сам процесс формирования польских школ был вызван желанием поляков-переселенцев вернуться на родину, т.е. в Польшу. Для этого следовало сохранить национальное самосознание и этническую идентичность, что сделало необходимым обучение детей польскому языку и польским традициям [1, с. 423]. Однако мы считаем, что вопрос о причинах создания поляками-переселенцами национальных школ имеет смысл рассмотреть глубже. Наше внимание привлекла позиция Н.М. Игнатовой. Этот исследователь рассматривает такие действия, как сохранение родного языка и соблюдение народных праздников, в контексте реализации потребности сохранения национальной культуры, что в свою очередь расценивается в качестве одной из форм духовного протеста [8, с. 6]. Возможно, что проживавшая в поселке исправительно-трудовой колонии (ИТК) Л. Милевич наряду с рациональной и относительно политически благонадежной потребностью в организационно-просветительской деятельности имела иррациональную потребность проявить протест против возникшей ситуации, т.е. против депортации польских семей. Подобная иррациональность могла найти отклик и у других взрослых поляков-переселенцев. В любом случае определение мотивации социально значимых поступков является одним из самых сложных в исторической науке, поскольку сопряжено с субъективными факторами.

Важно отметить, что Л. Милевич сумела сохранить протоколы родительских собраний, списки детей, журналы оценок, планы занятий, отчеты о работе кружков, поздравления с именинами. В Музее Независимости в Варшаве хранятся материалы, переданные сыном Л. Милевич - Лехом Милевичем и другими поляками. С некоторыми из документов удалось ознакомиться авторам данной статьи благодаря помощи научного сотрудника Музея Анны Милевской-Мвынек. Среди изученных музейных экспонатов следует назвать:

1) тетради по польскому языку учеников 6 класса школы № 2 (здесь и далее нумерация школы приведена по описям музея) для польских детей в Барнауле Ежи Ковальского и Ирмины Милевичувны (1945 г.);

2) тетрадь по географии ученицы 6 класса школы № 2 для польских детей в Барнауле Дануты Чискувны, содержащая сведения о морях, реках, озерах, вулканах, климате, растительности Европы, Азии, Америки, краткий политический 
обзор основных государств мира на польском языке (1944-1945 гг.);

3) записи о проведении занятий польского языка с подробным указанием даты, класса, темы, цели и метода проведения, домашнего задания.

Помимо этого, сохранилась программа празднования Дня независимости Польши (от 21 ноября 1943 г.), включавшая художественные выступления патриотического и интернационального содержания (хоровое пение, декламирование, танцы). Программа празднования 3 мая 1944 г. включала исполнение советских и польских гимнов, песен, танцев, чтение стихотворений. Э. Треля-Мазур писала о возникшем к 1945-1946 гг. интересе местных жителей к различным торжествам и мероприятиям, проводимым поляками [1, с. 426], чему, безусловно, способствовало создание польских школ в Барнауле.

Возвращаясь к непосредственной деятельности польских школ, заметим, что обстоятельством, затрудняющим процесс обучения в таких школах, стало отсутствие учебной литературы. Эту задачу решал Комитет по делам польских детей - государственное ведомство, созданное летом 1943 г. при Наркомате просвещения РСФСР. В 1944 г. член этого Комитета Г. Вольпе говорил: «За истекший год Комитет по делам польских детей проделал большую работу. Проведен учет польских детей и молодежи, создано 142 школы, 74 детсада и 47 детдомов, организован ряд курсов и семинаров для учителей, разрабатываются вопросы методики. Широко развертывается издательская деятельность Комитета по делам польских детей. При Комитете создана Комиссия по утверждению польских учебников. Изданные программы и учебники являются результатом примерно 10-месячной работы Комитета и Комиссии. $<\ldots>$ Издано уже шесть программ и семь учебников, преимущественно для начальной школы. Находятся в печати программа по истории Польши и четыре учебника. Готовится ряд других к предстоящему учебному году» $[18$, с. $30-31]$. Сложно ответить на вопрос: в полной ли мере польские школы были обеспечены учебной литературой? Официальные документы сообщают о том, что этот вопрос был решен. В частности, в феврале 1946 г. на организованной Всеславянским комитетом, ССП и Комитетом по делам польских детей встрече представителей советской и польской общественности с воспитанниками польских детских домов в СССР, возвращающимися в Польшу, заместитель Наркомпроса РСФСР С. Новиков, руководивший Комитетом по делам польских детей в СССР, заявил, что «20 тысяч польских детей на территории СССР обучались в польских школах и находились в детских домах. Кроме того, было создано 84 детских сада, а также польские группы при советских детских садах, в которых, в общей сложности, было до трех тысяч малышей. Все польские детские дома были обеспечены одеждой и продуктами питания. Для польских школ издано более 75 тысяч учебников на польском языке и около 18 тысяч различных учебных пособий. Польские дети, окончившие среднюю школу, поступили в высшие учебные заведения страны» [20, с. 48]. Между тем сложно сказать, соответствует ли эта официальная информация действительности тех лет и хватило ли изданных учебников для организации полноценного обучения, в том числе в польских школах Барнаула.

Подводя итоги изложенному выше, можно отметить, что, как и в целом по стране, в Барнауле и его окрестностях функционировали детские учреждения для польских детей: детские школы, детские сады, детский дом. Однако обстановка военного времени повлияла на сохранность отчетных документов. Поэтому сложно представить точную информацию о численности и нумерации польских школ. По мере развития военных событий и польско-советских отношений наблюдались изменения в позиции советского правительства к депортированным полякам. Создание СПП и Комитета по делам польских детей позволило получить польским школам организационную и материальную помощь, что сыграло положительную роль в развитии образовательных учреждений для польских детей. Проблемы же в развитии польских школ носили обыденный характер и возникали не только из-за тяжелых условий жизни депортированных польских семей, но и изза условий военного времени. В целом, благодаря активной деятельности как отдельных личностей (в Барнауле - Л. Милевич), так и институционально организованных СПП мероприятий, работа учебных заведений для польских детей в Барнауле на протяжении 1940-1946 гг. была налажена.

\section{Библиографический список}

1. Треля-Мазур Э. Депортированные поляки в Сибири (1940-1946): борьба за выживание // Сибирь в истории и культуре польского народа. М., 2002.
2. Иванов Ю.В. Польские дети в СССР во время Второй мировой войны // Новая и новейшая история. 2012. № 2. 
3. Авимская М.А. Осадники в Западной Сибири в годы Второй мировой войны // Вестник Псковского государственного университета. Серия: Социально-гуманитарные и психолого-педагогические науки. 2013. № 2.

4. Ложкина И.А. Польские и литовские дети в детских домах Удмуртии в годы Великой Отечественной войны // Вестник Удмуртского университета. Серия: История и филология. 2009. Вып. 2.

5. Подборская А. Поляки на берегах Енисея // День и ночь. 2008. № 1. URL: https://magazines.gorky.media/ din/2008/1/polyaki-na-beregah-eniseya.html.

6. Папков С.А. Сталинский террор в Сибири. 1928-1941. Новосибирск, 1997. URL: https://memorial. krsk.ru/Articles/1997Papkov/0.htm.

7. Скубневский В.А. Польские спецпереселенцы в Алтайском крае в годы Второй мировой войны // Краеведческие записки. Вып. 6. Барнаул, 2005.

8. Игнатова Н.М. Социальный и духовный протест спецпереселенцев в 1930-50-е гг. на Европейском Севере: постановка проблемы и интерпретация источников // Вестник Поморского университета. Серия: Гуманитарные и социальные науки. 2006. № 1.
9. Островский Л.К. Польская школа в Западной Сибири (1890-1920-е гг.) // Вестник Томского государственного университета. Серия: История. 2012. № 3(19).

10. Информация о типах учреждений для польских детей // Красная звезда. 1944. 28 мая. № 126 (5806).

11. Барнаул. Летопись города - хронология, события, факты / сост. А.М. Родионов. Барнаул, 2007.

12. Государственный архив Алтайского края (ГААК). Ф.Р-142. Оп.1. Д. 230.

13. ГААК. Ф.Р-142. Оп.1. Д. 219.

14. ГААК. Ф.Р-312. Оп. 1а. Д. 93.

15. Василевская В. Деятельность Союза польских патриотов в СССР // Славяне. 1943. №11.

16. Красная звезда. 1944. 28 мая. № 126 (5806).

17. ГААК. Ф.Р-573. Оп.1. Д. 470.

18. ГААК. Ф.Р-573. Оп.1. Д. 471.

19. Вольпе Г. Польские учебники в СССР [Текст] / Г. Вольпе // Славяне. 1944. № 7.

20. Польские дети возвращаются на Родину [Текст] // Славяне. 1946. № 2-3. 